\title{
ハイブリッド型応力法による鉄筋コンクリート造骨組の弾塑性崩壊解析 INELASTIC COLLAPSE ANALYSIS OF REINFORCED CONCRETE FRAMED STRUCTURES USING THE HYBRID STRESS FINITE ELEMENTS
}

\author{
稲田祐二*, 川端康洋**, 近藤一夫***, 玉井宏章 $* * * *$, 角 徹三***** \\ Yuji INADA, Yasuhiro KAWABATA, Kazuo KONDOH, \\ Hiroyuki TAMAI and Tetsuzo KAKU
}

\begin{abstract}
The hybrid stress beam-column finite elements, which have been proposed by Dr. Kondoh and based on the assumed stress method, yield no discretizing errors in their elastic and elasto-plastic responses, under the employed beam-column theory, of the member, with any (distributions of axial and flexural rigidity, and stress-strain characteristics) and subjected to any (concentrated and distributed) loads. Then, this approach might be one of the most promising approach to trace and examine the inelastic and collapse behavior of framed structures. In this paper, simple and effective hybrid stress finite element formulation is developed for reinforced concrete (R.C.) framed structures.

Based on the Timoshenko's beam-column theory considering the first order shear deformation, resultant stress-generalized strain relations of the R.C. beam-column section, which represent the well-known stiffness degrading characteristics of the R.C. member under the (axial forcing and bending) and their interaction, are formulated.

According to the standard procedure shown in Ref.17), the hybrid stress method, wherein employed the Lagrange multiplier method for computational convenience, is unifiedly formulated for the given basic equations and R.C. plane beam-column element is derived.

Several numerical tests are performed, and show that the present approach and element have excellent capacity to simulate simply and accurately the more complicate behavior of R.C. framed structures.
\end{abstract}

keyword:hybrid stress method, reinforced concrete framed structure, yield condition, cracking condition, collapse analysis ハイブリッド型応カ法，鉄筋コンクリート骨組構造，降伏条件，ひび割れ条件，崩壊解析

\section{1. はじめに}

鉄筋コンクリート（以下 R C と記す）造建物の耐震性能を的確に 評価するためには, 予想される種々の外乱に対して, 崩壊荷重, 崩 壊機構等の塑性崩壊状態に関する情報を含めた, 対象建物の弾塑性 応答挙動を, 十分な精度をもって予測しておく必要があり, 従っ て, 簡便で, 信頼性の高い解析手法, 離散化モデルの構築は, 耐震 性能評価精度向上のための必須条件であると思われる。こうした要 求に応えるため, これまでに，数多くのモデルが提案されてきた。 骨組構造物を対象とした代表的な部材要素モデルとしては, 材端ば ねモデル ${ }^{5)}$, 分割梁モデル ${ }^{6)}$, 柔性パラボラモデル7), 離散ばねモ デル ${ }^{8)}$, 柔域モテル ${ }^{9}$ 等のはり部材を対象とした 1 軸モテルと, ファイバーモデル(0)，金属塑性論に基づいたモデル111 13)， M $\mathrm{S} モ テ ゙ ル^{14)}$ 等の柱部材を対象とした軸力ー曲げモーメントの相互 作用を考虑した 2 軸あるいは 3 軸モテルが挙げられる。又, これら のモデル間の比較検討も一部なされている ${ }^{15)}$ 。各モテルとも, $\mathrm{R}$ C 部材特有の特性を比較的簡便に表現できるモテルとして提案され たものであり, 要求される解析レベルや解析条件に応じた適切なモ テルの選択が行われれば，その有用性は非常に高いと思われる。し かしながら, これらのモテルに共通する難点として, 部材中間分布 荷重の影響を厳密に考慮できないことが指摘される ${ }^{16)}$ 。さらに,
R C 部材に一般的に見られる部材軸方向の変断面特性や変形の進行 と共に生じる損傷の拡がりの影響を十分な汎用性と精度をもって評 価することは，例えば，損傷を受けることが予想される領域の要素 分割を細かくしたり，あるいは仮定する合応力場や変位場を高次化 する等の，何等かの特別の操作を施こさない限り，非常に困難なの が現状である。

一方, 近藤は, 文献 17 ) 等で, 鋼構造骨組の弾塑性崩壊挙動の 解析を主要な対象として, 古典的はり柱理論あるいは 1 次のせん断 変形を考虑したTimoshenkoはり柱理論を用いたハイブリッド型 応力法による骨組構造の離散化解析手法の提案を行っている。この 解析手法は，力のつり合いを基礎に考える応力法をベースとしなが らも, 要素境界上の平衡条件をゆるめたハイブリッド型の変分原理 を用いることにより, 最終的な未知量を節点変位のみとしているた め, 標準的解析プログラムに乗り易く, 又, 応力場は, 採用したは り柱理論の範鱚であれば, 平衡方程式から, その分布形状が一義的 に定まるため, 結果として, 材軸方向の剛性分布がどのような状態 となっても, 又, 部材中間分布荷重を受けるような場合について も, 離散化誤差は, 全く生じない。

ハイブリッド型応力法による離散化解析法は,これまで, 構成方 程式関係の取り扱いが比較的容易な，鋼構造骨組にのみ適用されて
注）本研究の一部は, 文献1)４）において発表している。

* 米子工業高等專門学校建築学科 助教授・工修

***米子工業高等専門学校建築学科 教授

***広島大学工学部建設構造工学 助教授. 工博

**** 広島大学工学部建設構造工学 助手. 工博

***** 豊橋技術科学大学建設工学系 教授. 工博
Assoc. Prof., Dept. of Architecture, Yonago National College of Technology, M. Eng.

Prof., Dept. of Architecture, Yonago National College of Technology

Assoc. Prof., Dept. of Struct. Eng., Faculty of Eng., Hiroshima University, Dr. Eng. Res. Assoc., Dept. of Struct. Eng., Faculty of Eng., Hiroshima University, Dr. Eng. Prof., Dept. of Civil and Architectural Eng., Toyohashi Univ. of Technology, Dr. Eng. 
いたが，その変形挙動を支配する主要な因子が材料非線形性である ような骨組の解析に対して, 絶大な威力を発揮するものであり, 又, 採用したはり柱理論内で処理しうるものであれば, 適用に際し ての材料特性に関する制限もない。従って, 龬棈造骨組に比して, はるかに複雑な材料特性を有する R C 骨組に対しても，適切な材料 あるいは断面特性の設定により, 前述したような従来のモテルに見 られたいくつかの難点も, 無理なく, 合理的に解消され, その弾塑 性崩壊挙動を組織的, 統一的に, 又, 精度よく追跡しうる強力な ツールとなることが期待される。

本報告では，このような観点から, Timoshenkoはり柱理論を 用いたハイブリッド型応力法による R C 平面骨組部材要素モテルの 定式化と, 誘導した要素モテルの有効性を検討するため, いくつか の数值解析を行った結果について報告する。本節での序文に引き 続き, 次節では, R C はり柱部材の断面特性の定式化が行われる。 そこでは, 文献 11 ）～１３）等を参考に、ひび割れ曲線及び降伏 曲線という 2 つの载荷曲線 ${ }^{18)}$ の概念が導入され, 軸力と曲げモー メントとの間の連成効果を考虑した 3 折れ線型の特性を有する一般 化ひずみ一合応力関係式が誘導される。ハイブリッド型応力法によ る定式化は，3 節で行われ， Lagrangeの未定乗数法を用いた基礎 変分原理が示されると共に, 要素両端の節点変位のみを最終的な未 知量とする要素剛性方程式が訜導される。又, 誘導した要素モデル の有効性を検討するために行った数值解析例は，4節に示される。 尚, ここでは, 外乱として, 単調載荷荷重を対象としており, 繰り 返し载荷の場合については, 報を改めて報告する予定である。

\section{RCはり柱部材の断面特性の定式化}

前述のように, ハイブリッド型応力法によるはり柱要素モデルで は, 弾塑性領域においても, 離散化誤差は全く生じない。従って, この要素の精度は, 採用した材料あるいは断面特性の設定如何によ り定まることになる。R C はり柱部材における損傷評価の方法とし ては，a）各ポイントごとに評価する方法，b）はり柱の断面全体 の損傷を評価する方法，c）部材あるいは要素全体としての損傷を 評価する方法の 3 つが考えられるが，本報告では，採用したはり柱 理論の適応性や計算効率, 汎用性等を勘案して, b ) の評価方法を 採用することとし，本節では，まず， R C はり柱部材断面の断面特 性を設定する。

さて，図 1 に示すような座標系を有する代表的 R C 平面はり柱部 材要䒺を考える。本研究では，はり柱に生じる塑性変形を，互いに 独立な曲げ変形成分と軸方向変形成分の 2 つの成分からなるものと し，単軸応力状態における曲げモーメントー曲率 $(\mathrm{M}-\kappa)$ 関係及 び軸力ー軸ひずみ $(N-\varepsilon)$ 関係を, それぞれ, 図 2 及び図 3 に示 すような 3 折線型に近似する。ここで, $N-\varepsilon$ 関係を 3 折線型の特 性としたのは，福澤等 ${ }^{123}$ が用いたのと同様な考え方に基づくもの であり，圧縮領域ではコンクリートの応カーひずみ関係の非線形性 を，又，引張り領域ではコンクリートのひび割れによる哃性低下を 考虙したものである。一方，せん断変形成分に関しては，その構成 方程式関係が，現状では十分明らかではないことを考慮し，弾性扱 いとする。

次に, 各断面での合応力間の連成効果を考虑するため, 載荷曲線 として, $\mathrm{M}-\mathrm{N}$ 応力空間内に, ひび割れ曲線： $\mathrm{f}$ と降伏曲線： $g$ を

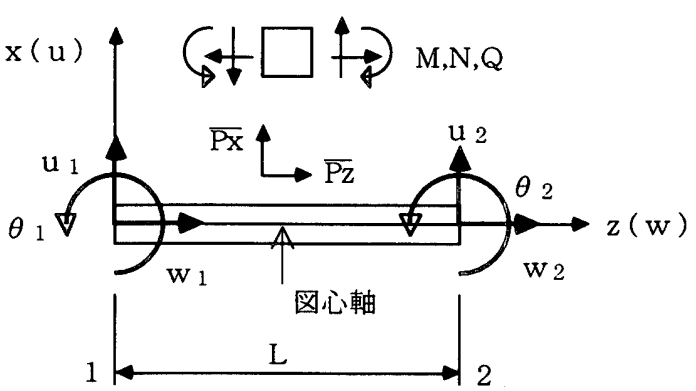

図 1 平面はり柱部材要素

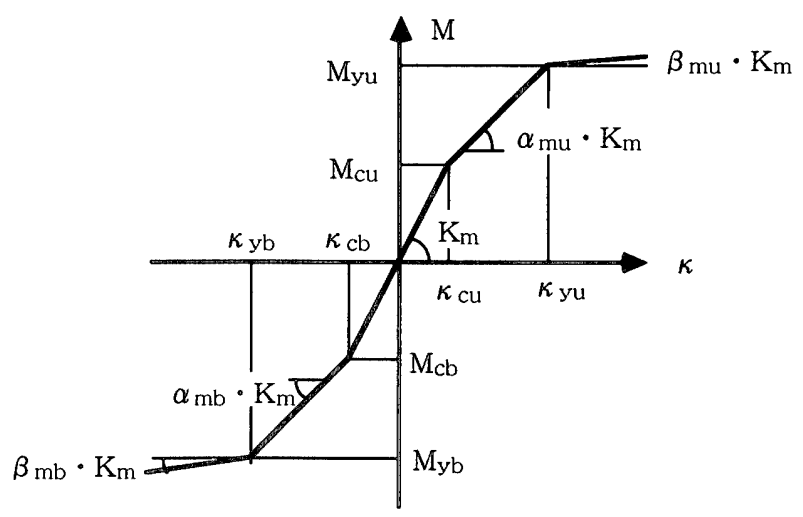

図 2 RCはり柱断面のM- $\kappa$ 関係

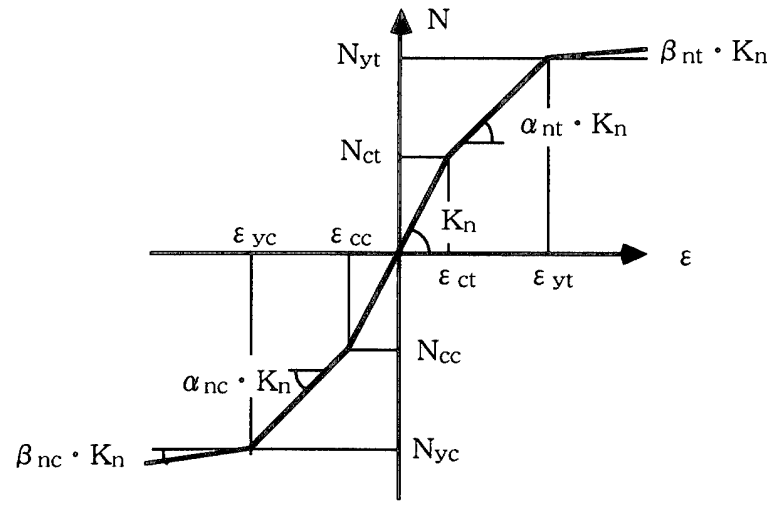

図 3 RCはり柱断面の $N-\varepsilon$ 関係

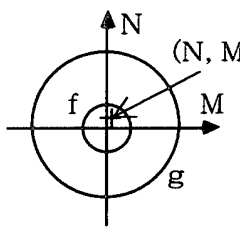

(a) 弾性領域

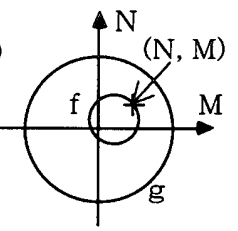

（b）ひび割れ領域

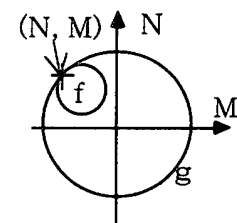

(c) 降伏領域
図 4 RCはり柱断面に出現する 3 つの応力状態

設定する。これらの曲線により，はり柱断面は，その応力状態によ って，図4に示すように，弾性領域，ひび割れ領域及び降伏領域の

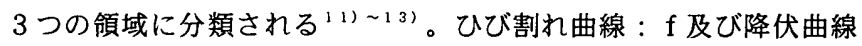
: $\mathrm{g}$ は, 与えられた 1 軸弾塑性特性に従い, 移動あるいは膨張する ものとすると, それぞれ，次式のように表わされる。

$$
\begin{aligned}
& f\left(M-c M^{*}, N-c N^{*}\right)=C_{c} \\
& g\left(M-y M^{*}, N-y N^{*}\right)=C_{y}
\end{aligned}
$$

ここに, $\mathrm{M}, \mathrm{N} は$ 現在の合応力, $\mathrm{cM}^{*}, \mathrm{cN}^{*}$ はひび割れ曲線の中 
心, $\mathrm{yM}^{*}, \mathrm{yN}^{*}$ は降伏曲線の中心, $\mathrm{Cc}, \mathrm{Cy}$ はそれぞれの曲線の大 きさを表わすパラメータである。

ひび割れ領域及び降伏領域における付加塑性一般化ひずみ增分べ クトル $\{\Delta \mathrm{DC}\}=\{\Delta \kappa \mathrm{C}, \Delta \varepsilon \mathrm{C}\}^{\mathrm{T}},\{\Delta \mathrm{Dy}\}=\{\Delta \kappa \mathrm{y}, \Delta \varepsilon \mathrm{y}\}^{\mathrm{T}}$ は，塑性流れ則に従えば，それぞれ，次式のように表わされる。

$$
\begin{aligned}
& \left\{\Delta \mathbf{D}_{\mathrm{c}}\right\}=\Delta \lambda_{\mathrm{c}}\{(\partial \mathrm{f} / \partial \mathrm{M}), \quad(\partial \mathrm{f} / \partial \mathrm{N})\}^{\mathrm{T}}=\Delta \lambda_{\mathrm{c}}\left\{\mathbf{F}_{\mathrm{n}}\right\} \\
& \left\{\Delta \mathbf{D}_{\mathrm{y}}\right\}=\Delta \lambda_{\mathrm{y}}\{(\partial \mathrm{g} / \partial \mathrm{M}), \quad(\partial \mathrm{g} / \partial \mathrm{N})\}^{\mathrm{T}}=\Delta \lambda_{\mathrm{y}}\left\{\mathbf{G}_{\mathrm{n}}\right\}
\end{aligned}
$$

ここに， $\Delta \lambda \mathrm{c} ， \Delta \lambda \mathrm{y}$ は，付加塑性一般化ひずみ増分の大きさ を示すスカラー量であり $, \Delta \lambda c<0, \Delta \lambda \mathrm{y}<0$ の時, 除荷状態 となる。

一方, 合応力增分ベクトル $\{\Delta \mathrm{q}\}=\{\Delta \mathrm{M}, \Delta \mathrm{N}\}^{\top}$ には, 增分後も ひび割れ及び降伏曲線上にあるための条件として, 次式の増分型塑 性条件式が賦与される。

$$
\begin{aligned}
& \left\{\mathbf{F}_{\mathrm{n}}\right\}^{\mathrm{T}} \cdot\left(\{\Delta \mathbf{q}\}-\Delta \lambda_{\mathrm{c}}[\mathrm{cH}]\left\{\mathbf{F}_{\mathrm{n}}\right\}\right)=0 \\
& \left\{\mathbf{G}_{\mathrm{n}}\right\}^{\mathrm{T}} \cdot\left(\{\Delta \mathbf{q}\}-\Delta \lambda_{\mathrm{y}}[\mathrm{y} \mathbf{H}]\left\{\mathbf{G}_{\mathrm{n}}\right\}\right)=0 \\
& \text { … (3. a, b) } \\
& \text { ここに， } \\
& {[\mathrm{c} \mathbf{H}]=\left[\begin{array}{cc}
\mathrm{cH}_{\mathrm{m}} & 0 \\
0 & \mathrm{cH}_{\mathrm{n}}
\end{array}\right]} \\
& {[y \mathbf{H}]=\left[\begin{array}{cc}
\mathrm{yH}_{\mathrm{m}} & 0 \\
0 & \mathrm{y}_{\mathrm{n}}
\end{array}\right]}
\end{aligned}
$$

であり, $\mathrm{cHm}, \mathrm{cHn}, \mathrm{yHm}, \mathrm{yHn}$ は, 図 2 及び図 3 のように設定 した 1 軸弾塑性特性から, それぞれ, 次式のように定まる硬化係数 である。

$$
\begin{aligned}
& { }_{c} H_{m}=\alpha_{m i}\left(1-\alpha_{m i}\right)^{-1} K_{m} \\
& { }_{c} H_{n}=\alpha_{n j}\left(1-\alpha_{n j}\right)^{-1} K_{n}
\end{aligned}
$$

又

$$
\begin{aligned}
& { }_{y} H_{m}=\beta_{m i} \alpha_{m i}\left(\alpha_{m i}-\beta_{m i}\right)^{-1} K_{m} \\
& { }_{y} H_{n}=\beta_{n j} \alpha_{n j}\left(\alpha_{n j}-\beta_{n j}\right)^{-1} K_{n}
\end{aligned}
$$

ここに，添字 $\mathrm{i}$ 及び $\mathrm{j}$ は，対応する合応力の値の正負により，そ れぞれ，( $\mathrm{u}, \mathrm{b})$ 及び $(\mathrm{t}, \mathrm{c})$ となる。

(2. a,b) 及び (3.a,b) 式がひび割れ領域及び降伏領域にお けるはり柱の断面剛性を定める基礎式である。尚，（4. a, b) 式 の硬化係数が 0 でなければ，(2.a,b) 及び (3.a,b) 式より， 一般化ひずみ増分一合応力增分関係を導くことも容易に可能である が，ひび割れ曲線及び降伏曲線として，折れ線を含む種々の形状の ものを，比較的容易に処理可能であること，硬化係数が 0 となって も何等の問題も生じないこと等のことを考虑して, 本研究では, 次 節に示すように，（3，a，b）式で与えられる増分型の塑性条件 を，合応力場に課せられる新たな付帯条件と考え， Lagrangeの末 定乗数を適用するという手法を採用する。

\section{3. ハイブリッド型応カ法による定式化}

次に，ハイブリッド型応力法による R C 平面はり柱部材要素モデ ルの誘導を行う。

\section{1 基礎変分原理}

部材要素両端の変位增分ベクトルを $\{\Delta \mathrm{d} \mathrm{m}\}=\left\{\Delta \mathrm{w}_{1}, \Delta \mathrm{u}_{1}\right.$, $\left.\Delta \theta_{1}, \Delta \mathrm{w}_{2}, \Delta \mathrm{u}_{2}, \Delta \theta_{2}\right\}^{\mathrm{T}}$, 合応力表示された材端力增分べクト ルを $\{\Delta T\}=\left\{-\left.\Delta N\right|_{1},-\left.\Delta Q\right|_{1},\left.\Delta M\right|_{1},\left.\Delta N\right|_{2},\left.\Delta Q\right|_{2}\right.$ ， $\left.-\left.\Delta M\right|_{2}\right\}^{\top}$ と表わし, ひび割れ領域及び降伏領域で与えられる (3.a，b）式の增分型の塑性条件を, 合応力場に課せられる新た な付帯条件としてLagrangeの未定乗数法を適用すると，ハイブリ ッド型停留コンプリメンタリーエネルギーの原理の增分型汎関数 : $\Delta \Pi^{\mathrm{m}}$ は，次式となる。

$$
\begin{aligned}
\Delta \Pi^{\mathrm{m}} & =\int_{0}^{\mathrm{L}}(-\Delta £) \mathrm{dz}+\{\Delta \mathbf{T}\}^{\mathrm{T}} \cdot\left\{\Delta \mathbf{d}_{\mathrm{m}}\right\} \\
& -\int_{\ell_{\mathrm{c}}}\left[\Delta \lambda_{\mathrm{c}}\left\{\mathbf{F}_{\mathrm{n}}\right\}^{\mathrm{T}} \cdot\left(\{\Delta \mathbf{q}\}-\frac{1}{2} \Delta \lambda_{\mathrm{c}}[\mathbf{c H}]\left\{\mathbf{F}_{\mathrm{n}}\right\}\right)\right] \mathrm{dz} \\
& -\int_{\ell_{\mathrm{y}}}\left[\Delta \lambda_{\mathrm{y}}\left\{\mathbf{G}_{\mathrm{n}}\right\}^{\mathrm{T}} \cdot\left(\{\Delta \mathbf{q}\}-\frac{1}{2} \Delta \lambda_{\mathrm{y}}[\mathbf{y} \mathbf{H}]\left\{\mathbf{G}_{\mathrm{n}}\right\}\right)\right] \mathrm{d} \mathbf{z}
\end{aligned}
$$

ここに, $\Delta £ は$, 単位長さ当たりの弾性コンプリメンタリーエネ ルギーの增分, 又, $\Delta \lambda \mathrm{c}$ 及び $\Delta \lambda \mathrm{y}$ は, 付加塑性一般化ひずみ增 分の大きさを表わすパラメータという物理的意味を有する

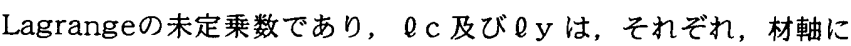
沿ったひび割れ及び降伏領域である。

（7）式における独立関数は，該当の節点を共有する隣接する部 材要素について共通に定義される $\{\Delta \mathrm{dm}\}$ と，各部材要素につい て独立に与えられる $\Delta \mathrm{N}, \Delta \mathrm{M}, \Delta \mathrm{Q}$ 及び $\Delta \lambda \mathrm{c}, \Delta \lambda \mathrm{y}$ であり， 又, 付帯条件は, 次式で与えられる, 要素内部の增分型の平衡方程 式である。

$$
\begin{array}{ll}
\frac{\mathrm{d} \Delta \mathrm{N}}{\mathrm{d} z}+\Delta \overline{\mathrm{P}}_{\mathrm{z}}=0 & \frac{\mathrm{d} \Delta \mathrm{M}}{\mathrm{dz}}-\Delta \mathrm{Q}=0 \\
\frac{\mathrm{d} \Delta \mathrm{Q}}{\mathrm{dz}}+\Delta \overline{\mathrm{P}}_{\mathrm{x}}=0 &
\end{array}
$$

ここに， $\Delta \overline{\mathrm{P}} \mathrm{z}$ 及び $\Delta \overline{\mathrm{P}} \mathrm{x}$ は，それぞれ，単位長さ当たりの $z$ 及び $\mathrm{x}$ 軸方向の部材中間分布荷重の増分である。

\section{2 R C 平面はり柱要素モデルの誘道}

付帯条件である（8，a～c）式の增分型平衡方程式を満足する合 応力場は, 次式のように表わされる。

$$
\begin{aligned}
& \Delta \mathrm{N}=\Delta \mathrm{n}+\Delta \overline{\mathrm{N}}_{(\mathrm{p})} \\
& \Delta \mathrm{M}=(1-\mathrm{z} / \mathrm{L}) \cdot \Delta \mathrm{m}_{1}+(\mathrm{z} / \mathrm{L}) \cdot \Delta \mathrm{m}_{2}+\Delta \overline{\mathrm{M}}_{(\mathrm{p})} \quad \ldots(9 . \mathrm{a} \sim \mathrm{c}) \\
& \Delta \mathrm{Q}=(-1 / \mathrm{L}) \cdot \Delta \mathrm{m}_{1}+(1 / \mathrm{L}) \cdot \Delta \mathrm{m}_{2}+\Delta \overline{\mathrm{Q}}_{(\mathrm{p})}
\end{aligned}
$$

又,

$$
\begin{aligned}
& \Delta \overline{\mathrm{N}}_{(\mathrm{p})}=\int_{0}^{\mathrm{z}} \Delta \overline{\mathrm{P}}_{\mathrm{z}} \mathrm{dz} \\
& \Delta \overline{\mathrm{M}}_{(\mathrm{p})}=\int_{0}^{\mathrm{z}}\left(\int_{0}^{\mathrm{z}} \Delta \overline{\mathrm{P}}_{\mathrm{x}} \mathrm{dz}\right) \mathrm{dz}+\left(\frac{\mathrm{z}}{\mathrm{L}}\right) \int_{0}^{\mathrm{L}}\left(\int_{0}^{\mathrm{z}} \Delta \overline{\mathrm{P}}_{\mathrm{x}} \mathrm{dz}\right) \quad . \quad(10 . \mathrm{a} \sim \mathrm{C}) \\
& \Delta \overline{\mathrm{Q}}_{(\mathrm{p})}=\int_{0}^{\mathrm{z}} \Delta \overline{\mathrm{P}}_{\mathrm{x}} \mathrm{dz}+\left(\frac{1}{\mathrm{~L}}\right) \int_{0}^{\mathrm{L}}\left(\int_{0}^{\mathrm{z}} \Delta \overline{\mathrm{P}}_{\mathrm{x}} \mathrm{dz}\right) \mathrm{dz}
\end{aligned}
$$

ここに, $\{\Delta \mathrm{S} \mathrm{m}\}=\left\{\Delta \mathrm{n}, \Delta \mathrm{m}_{1}, \Delta \mathrm{m}_{2}\right\}^{\top}$ は, 各部材要素で独立 に与えられる合応力パラメータの増分ベクトルである。

さて, 本研究では, ひび割れ領域及び降伏領域の材軸方向への拡 


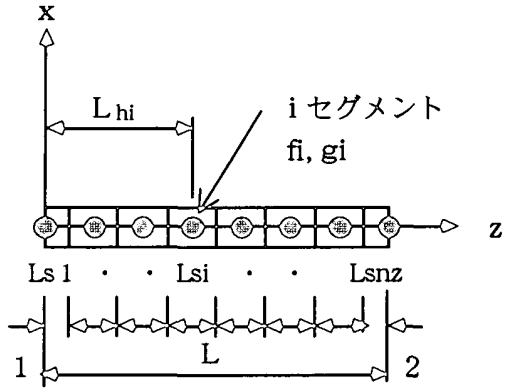

図 5 要素のセグメント分割

がりや，はり柱の変断面特性を評価するため, 各はり柱要素を, 図 5 に示すように，材軸方向に微小なセグメントに分割し，はり柱の 断面の損賃及び㖄性は各セグメント内で一定であるものとして, セ グメント内に 1 個ずつ設けた一般化ひずみ, 合応力評価点における 値を用いて算出することにする。又, エネルギー䅡分は, 弾性コン プリメンタリーエネルギーについては, 正確に算出するが, その他 の諸量については, 計算の簡略化を計るため, 一般化ひずみ, 合応 力算定点の値を用いて代表させる。

（9. a〜c）式を（7）式に代入し，前述のような㴊性謤価及びエ ネルギー算定の方法を用いて整理すると, $\Delta \Pi^{\mathrm{m}}$ は, 次式のように 書ける。

$$
\begin{aligned}
\Delta \Pi^{m}=- & \frac{1}{2}\left\{\Delta \hat{S}_{m}\right\}^{T}\left[\hat{\mathbb{A}}_{s s}\right]\left\{\Delta S_{m}\right\}-\left\{\Delta \hat{S}_{m}\right\}^{\mathrm{T}}\left\{\Delta \hat{B}_{s}\right\} \\
& +\left\{\Delta S_{m}\right\}^{\mathrm{T}}\left[\hat{\mathbb{A}}_{s d}\right]\left\{\Delta d_{m}\right\}+\left\{\Delta \mathbb{B}_{d}\right\}^{\mathrm{T}}\left\{\Delta \mathbb{d}_{m}\right\}
\end{aligned}
$$

ここに,

$\left\{\Delta \hat{S}_{m}\right\}=\left\{\left\{\Delta S_{m}\right\}^{T}, \Delta \lambda c_{1}, \cdots, \Delta \lambda c_{m c}, \Delta \lambda y_{1}, \cdots, \Delta \lambda y_{m y}\right\}^{T} \quad \ldots$

又 $\left[\hat{\mathrm{A}}_{\mathrm{ss}}\right]$ ，は, $(3+\mathrm{mc}+\mathrm{my}) \times(3+\mathrm{mc}+\mathrm{my})$ の対称マト リックスであり, ゼロ以外の成分 : $a_{i j}=a_{j 1}$ を示すと, 以下のよ うになる。

$$
\left[\begin{array}{lll}
a_{11} & a_{12} & a_{13} \\
a_{21} & a_{22} & a_{23} \\
a_{31} & a_{32} & a_{33}
\end{array}\right]=\int_{0}^{L}\left[\mathbb{H}_{s}\right]^{T}[\mathbb{C}]\left[\mathbb{H}_{s}\right] d z
$$

$4 \leqq i \leqq(3+m c)$ :

$$
\begin{array}{ll}
a_{1 i}=L_{s i} \cdot(f),\left.N\right|_{z=L h i} & a_{2 i}=L_{s i} \cdot\left(1-\frac{L h i}{L}\right)(f),\left.M\right|_{z=L h i} \\
a_{3 i}=\left.L_{s i} \cdot\left(\frac{L h i}{L}\right)(f)_{M}\right|_{z=L h i} & a_{i i}=\left.L_{s i} \cdot\left[H_{m}(f), M_{M}^{2}+H_{n}(f),{ }_{N}^{2}\right]\right|_{z=L h i}
\end{array}
$$$$
\cdots(13 . b \sim e)
$$

$(4+m c) \leqq i \leqq(3+m c+m y):$

$$
\begin{array}{ll}
a_{1 i}=\left.L_{s i} \cdot(g)_{, N}\right|_{z=L h i} & a_{2 i}=\left.L_{s i} \cdot\left(1-\frac{L h i}{L}\right)(g)_{M}\right|_{z-L h i} \\
a_{3 i}=\left.L_{s i} \cdot\left(\frac{L h i}{L}\right)(g)_{M}\right|_{z=L h i} & a_{i i}=\left.L_{s i} \cdot\left[y H_{m}(g)_{M}^{2}+y H_{n}(g){ }_{N}^{2}\right]\right|_{z=L h i}
\end{array}
$$

ここに, ( ), ${ }_{\mathrm{M}}=\partial() / \partial \mathrm{M},(\quad),_{\mathrm{N}}=\partial(\quad) / \partial \mathrm{N}$ の記号を 用いている。

更に,

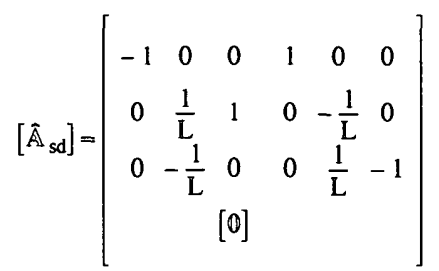

$$
\left\{\hat{\mathbb{B}}_{s}\right\}=\left\{\begin{array}{c}
\left\{\int_{0}^{L}\left[\mathbb{R}_{s}\right]^{T}[\mathbb{C}]\left\{\Delta \overline{\mathbb{S}}_{(p)}\right\} d z\right\} \\
\left.L_{s i}\left[\left\{\Delta \overline{\mathbb{M}}_{(p)}, \Delta \overline{\mathbb{N}}_{(p)}\right\}\left\{\mathbb{F}_{n}\right\}\right]\right|_{z=L_{h 1}} \\
\vdots \\
\left.L_{s i}\left[\left\{\Delta \overline{\mathbb{M}}_{(p)}, \Delta \overline{\mathbb{N}}_{(p)}\right\}\left\{\mathbb{F}_{n}\right\}\right]\right|_{z=L_{h m c}} \\
\left.L_{s i}\left[\left\{\Delta \overline{\mathbb{M}}_{(p)}, \Delta \overline{\mathbb{N}}_{(p)}\right\}\left\{\mathbb{G}_{n}\right\}\right]\right|_{z=L_{h 1}} \\
\vdots \\
\left.L_{s i}\left[\left\{\Delta \overline{\mathbb{M}}_{(p)}, \Delta \overline{\mathbb{N}}_{(p)}\right\}\left\{\mathbb{G}_{n}\right\}\right]\right|_{z=L_{h m y}}
\end{array}\right\}
$$

$\left\{\Delta \mathbb{B}_{\mathrm{d}}\right\}=\left\{-\left.\Delta \mathbb{\mathbb { N }}_{(\mathrm{p})}\right|_{1},-\left.\Delta \overline{\mathrm{Q}}_{(\mathrm{p})}\right|_{1},\left.\Delta \mathbb{\mathbb { Z }}_{(\mathrm{p})}\right|_{1},\left.\Delta \mathbb{\mathbb { V }}_{(\mathrm{p})}\right|_{2},\left.\Delta \overline{\mathrm{Q}}_{(\mathrm{p})}\right|_{2},-\left.\Delta \mathbb{\mathbb { Z }}_{(\mathrm{p})}\right|_{2}\right\}^{\mathrm{T}}$

$$
\begin{aligned}
& {\left[\mathbb{H}_{s}\right]=\left[\begin{array}{ccc}
1 & 0 & 0 \\
0 & 1-\mathrm{z} / \mathrm{L} & \mathrm{z} / \mathrm{L} \\
0 & -1 / \mathrm{L} & 1 / \mathrm{L}
\end{array}\right]} \\
& \left\{\Delta \overline{\mathrm{S}}_{(\mathrm{p})}\right\}=\left\{\Delta \overline{\mathrm{N}}_{(\mathrm{p})} \Delta \overline{\mathrm{M}}_{(\mathrm{p})} \Delta \overline{\mathrm{Q}}_{(\mathrm{p})}\right\}^{\mathrm{T}}
\end{aligned}
$$

であり，mc，myは，それぞれ，ひび割れ領域及び降伏領域に属 するセグメント数, [ C ] は, 3 行× 3 列の弾性断面桑性マトリッ クス, [0]は, $(\mathrm{mc}+\mathrm{my})$ 行 $\times 6$ 列のゼロマトリックスであ る。

（11）式の第 1 変分を取ると

$$
\begin{aligned}
\delta \Delta \Pi^{\mathrm{m}} & =\left\{\delta \Delta \hat{\mathrm{S}}_{\mathrm{m}}\right\}^{\mathrm{T}}\left\langle-\left[\hat{\mathrm{A}}_{\mathrm{ss}}\right]\left\{\Delta \mathrm{S}_{\mathrm{m}}\right\}-\left\{\Delta \hat{\mathrm{B}}_{\mathrm{s}}\right\}+\left[\hat{\mathrm{A}}_{\mathrm{sd}}\right]\left\{\Delta \mathrm{d}_{\mathrm{m}}\right\}\right\rangle \\
& +\left\{\delta \Delta \mathrm{d}_{\mathrm{m}}\right\}^{\mathrm{T}}\left\langle\left[\hat{\mathrm{A}}_{\mathrm{sd}}\right]^{\mathrm{T}}\left\{\Delta \hat{\mathrm{S}}_{\mathrm{m}}\right\}+\left\{\Delta \hat{\mathrm{B}}_{\mathrm{d}}\right\}\right\rangle
\end{aligned}
$$

$\left\{\Delta \mathrm{S}_{\mathrm{m}}\right\}$ は, 各要素で独立であるから, その停留条件として, 次 式を得る。

$$
\left\{\Delta \hat{S}_{m}\right\}=\left[\hat{\mathrm{A}}_{s s}\right]^{-1}\left[\hat{\mathrm{A}}_{\mathrm{sd}}\right]\left\{\Delta \mathrm{d}_{\mathrm{m}}\right\}-\left[\hat{\mathrm{A}}_{\mathrm{ss}}\right]^{-1}\left\{\Delta \hat{\mathrm{B}}_{\mathrm{s}}\right\}
$$

（20）式を，再び，（19）式に代入，整理すると，次式のような 要紊両端の変位增分ベクトルのみを圭知量とする, 部材要意甽性方 程式が得られる。

$$
\delta \Delta \Pi^{\mathrm{m}}=\left\{\delta \Delta \mathrm{d}_{\mathrm{m}}\right\}^{\mathrm{T}}\left\langle\left[\mathrm{K}_{\mathrm{m}}\right]\left\{\Delta \mathrm{d}_{\mathrm{m}}\right\}-\left\{\Delta F_{\mathrm{m}}\right\}\right\rangle
$$

ここに,

$$
\begin{gathered}
{\left[\mathbb{K}_{\mathrm{m}}\right]=\left[\overline{\mathbb{A}}_{\mathrm{sd}}\right]^{\mathrm{T}}\left[\overline{\mathbb{A}}_{\mathrm{ss}}\right]^{-1}\left[\hat{\mathbb{A}}_{\mathrm{sd}}\right]} \\
\left\{\Delta \mathbb{F}_{\mathrm{m}}\right\}=\left[\widehat{\mathbb{A}}_{\mathrm{sd}}\right]^{\mathrm{T}}\left[\widehat{\mathbb{A}}_{\mathrm{ss}}\right]^{-1}\left\{\Delta \hat{\mathbb{B}}_{\mathrm{s}}\right\}-\left\{\Delta \mathbb{B}_{\mathrm{d}}\right\}
\end{gathered}
$$


であり， $[\mathrm{Km}]$ が部材要素の瞬間剛性マトリックス, $\{\Delta \mathrm{Fm}\}$ が部材要素中間荷重による增分荷重ベクトルである。

部材要素両端の変位増分ベクトルは, 該当の節点を共有するすべ ての要素について共通に定義されることを考虑して，（21）式を すべての部材要素について奇せ集めれば， R C 骨組の構造全体とし ての剛性方程式が得られる。

一方, 剛性方程式より求められる変位増分ベクトルを, 部材要素 ごとに，（20）式に代入すれば， $\left\{\Delta \mathrm{S}_{\mathrm{m}}\right\}$ が, 又, $\left\{\Delta \mathrm{S}_{\mathrm{m}}\right\}$ と弾性断面 柔性マトリックス: [C] より求められる一般化ひずみ增分を材軸 方向に積分すれば変位が定まり ${ }^{4)}$, すべての状態量が求められ る。

\section{4. 数值解析例}

本節では，前節までに誘導した R C 平面はり柱部材要素モデルの 精度，有効性等を検証するため，いくつかの数値解析を行った結果 について報告する。尚，本節の 4.2 項及び 4.3 項に示す弾塑性崩 壊解析では，2節に示した 2 つの載荷曲線 $\mathrm{f}$ 及び $\mathrm{g}$ は，その大きさ 及び形状は変わらず，Zieglerの移動硬化則に従い移動するものと し，又，その形状は，共に，曲げモーメントのみを考慮した，次式 としている(1)。

$$
\mathrm{f}(\mathrm{M})=\left|\mathrm{M} / \mathrm{M}_{\mathrm{c}}\right|, \quad \mathrm{g}(\mathrm{M})=\left|\mathbf{M} / \mathrm{M}_{\mathrm{y}}\right| \quad \cdots(23, \mathrm{a}, \mathrm{b})
$$

剛域 : $E \times 10^{6}, I \times 10^{6}$ (一定) 可撓域 : E, I（一定）

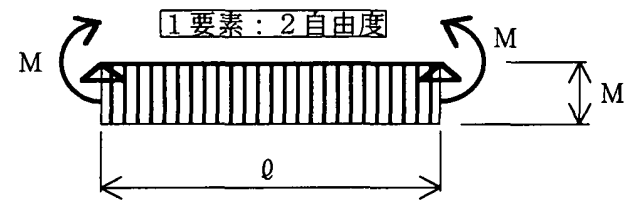

図 6 両端に曲げを受ける弾性ばり

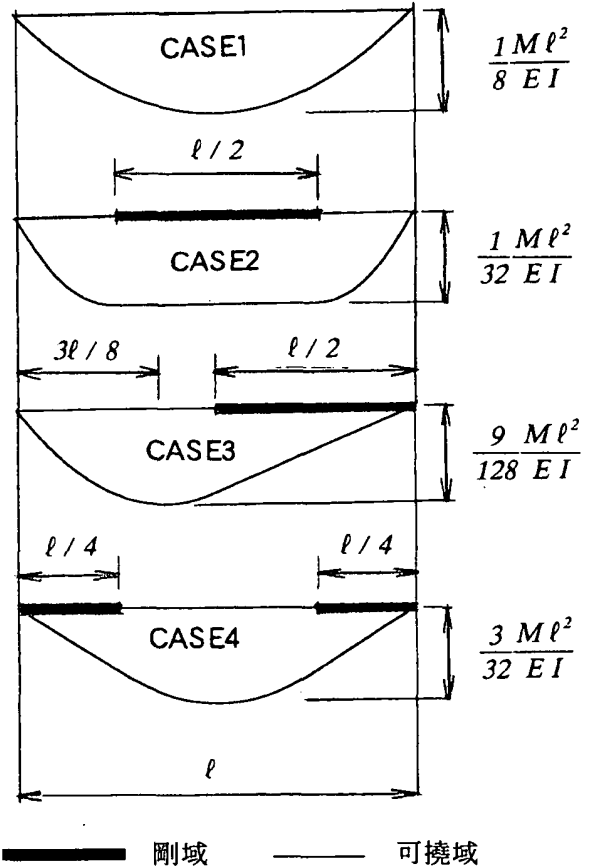

図 7 部分剛域を有するはりの変形性状

\section{1 部分判域を有するはりの解析}

R Cはり・柱部材の中間部に腰壁や袖壁が存在する場合，その区 間の剛性は急激に增大する。本報告で提示しているモデルでは, 部 材要素内部に，このような部分的に剛な領域を含んだような場合に も，そうした領域に特別な操作を施す必要はなく，他の領域と全く 同様に扱える。又，もし，必要であれば，剛域内に塑性ヒンジを挿 入することも容易に可能である。本節では，まず，このような変断 面部材の数值解析例として, 図 6 及び図 7 に示すような, 部分剛域 を有する弾性単純ばりの純曲げ解析を行った。用いた要素数は 1 , 全自由度数は 2 である。又, セグメント分割数 : $\mathrm{n} 2$ は 41 とした。 解析パラメー夕は部分剛域 ${ }^{2}$ 'の位置と長さであり，図 7 の CASE1〜CASE4の 4 つのケースを設定した。解析より得られた変 位分布をデフォルメしたものを, 最大たわみの理論値と共に, 図 7 に示す。解析精度の誤差は，すべてのケースについて，1\%以下で あり ${ }^{(3)}$ ，各々のケースの特徵ある変位分布を精度よく再現してい ることがわかる。

\section{2 山形ラーメンの弾塑性崩壊解析}

次に，文献19）で取り扱われている，図 8 に示すような，一定鈶 直荷重下で各層に横方向漸增荷重を受ける 3 層山形ラーメンの弾塑 性崩壊解析を行った。この山形ラーメンは，3 階屋根中間部に塑性 ヒンジが生じて崩壊状態に至ることが知られている。解析諸元は,

基本的には，文献19）に示されたものを用いたが，変形解析用諸元 として，曲げモーメントー曲率関係を，図 9 のように仮定し，各部 材の断面定数は, 図 8 に示すように設定した。用いた要素数は 10 ,

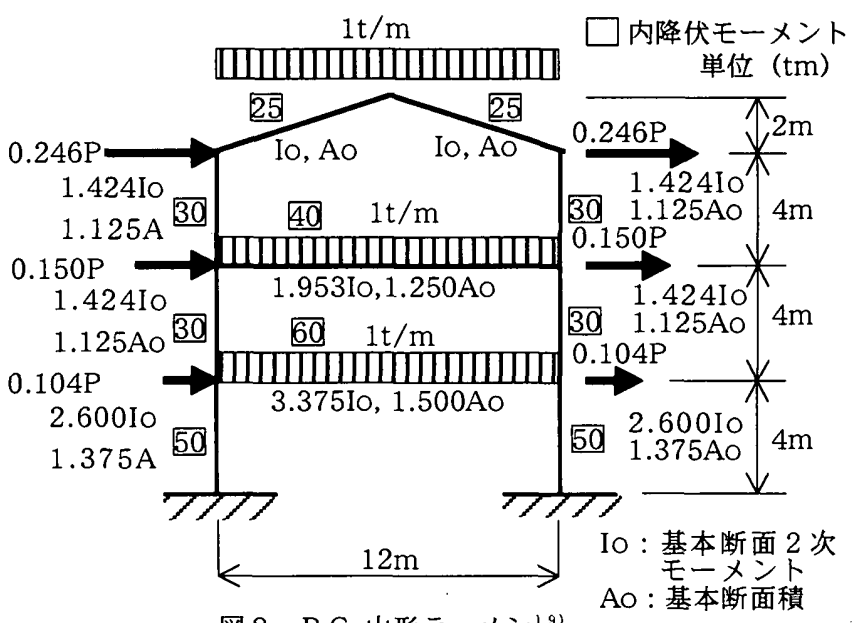

図 8 R C 山形ラーメン19 Ao : 基本断面積

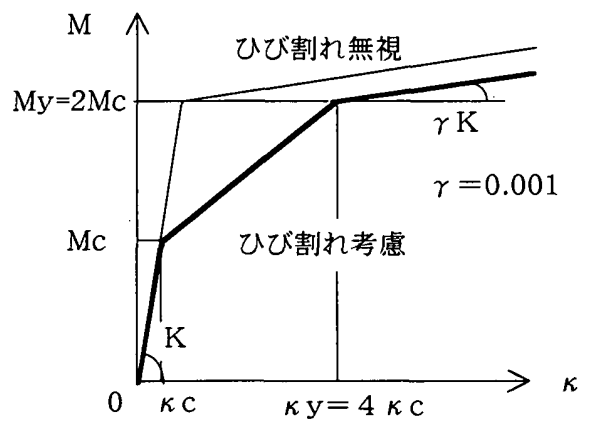

図 9 曲げモーメントー曲率関係 


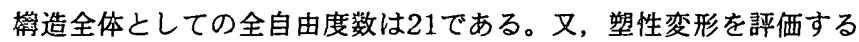
単位であるセグメントは，断面形状が与えられていないので，柱に ついては，11分割，一方，はりについては，21分割とした。横方 向荷重の大きさ : P と 3 階左柱頭部の横方向変位 : $\delta$ との間の関係

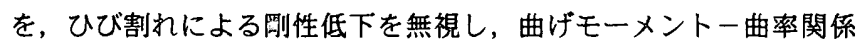
を，図 9 の細実線のように設定した場合の結果及び文献19）に与 えられている崩壊荷重と共に，図10に示す。又，図11及び図12に は，新たな降伏が生じた各変形レベルにおける曲げモーメント分布 及び山形ラーメンの変形性状を示す。尚, 図11の図中の○，は， それぞれ，ひび割れ領域及び降伏領域に達したセグメントの意味で ある。又, 同図中の数字は, 降伏領域に達したセグメントについ て，その発生順序を表したものであり, 同じ数値を付した図10及び 図12の各変形段階に対応する。

$(\mathrm{tf})$

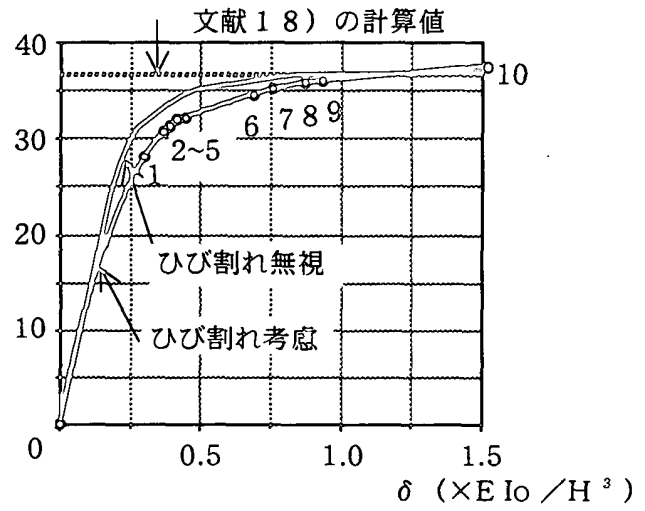

図 10 山形ラーメンの荷重一変形関係

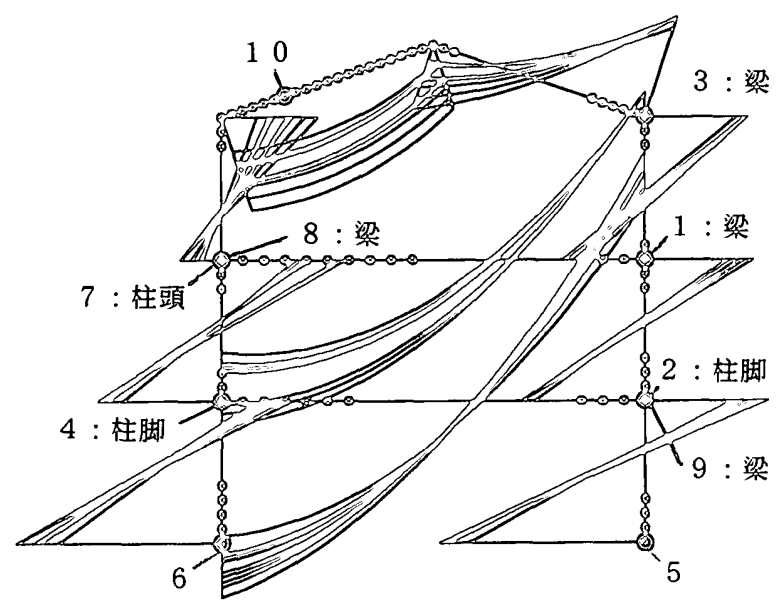

○ひび割れ状態，○降伏状態，数値は降伏の発生順序

図 11 山形ラーメンの曲げモーメント分布

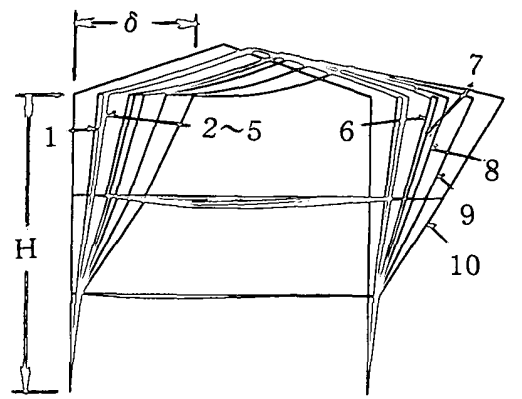

9 節点

10 要素

21 自由度 これ等の結果より，i）本解析解は，崩萝荷重，崩壊メカニズム 共に, 文献19）に示されている結果と良好に一致すること, 又, ii）本解析手法によれば,これまで非常に图難であった，ひび割れ 領域や降伏領域の進展等に関する情報も十分得られること，更に は, iii）損甥域の拡大に伴って生じる剛性低下や, 内力分布の変钦 等も的確に䛨価されうること，等のことがわかる。

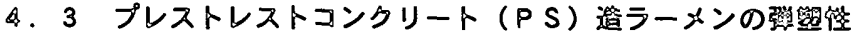

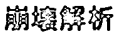

本節に示す最後の解析例題は，文献20）の付 2 に示されている 架楧の一部を取り出した，図13に示すようなPS部分架鹤である。 この解析モデルは，変断面強度部枋についての例題として選定した ものであり，変断面強度部枋であるPSはりに注目するために，以下 のような仮定を導入した。即ち, PS柱は無限強度を有する弾性柱と し，施工等による不静定応力等は考虑しない。又，柱・はり接合部 は剛域として扱う。解析諸元は文献19）と同様であり，PSはりの 曲げモーメントー曲率関係は，図 9 の 3 折れ線型とした。又, 変断 面特性として,このはりは，上端引張，下端引張のそれぞれの場合 について，図14に示すような放物線状の降伏モ一メント值を有する ものとした。解析に用いた要素数は，柱 : 2 要素 $\times 2$, はり：1要

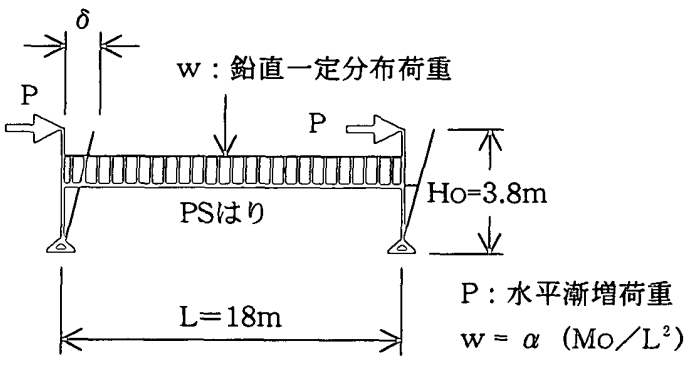

図 13 プレストレストコンクリート造骨組の部分架榜

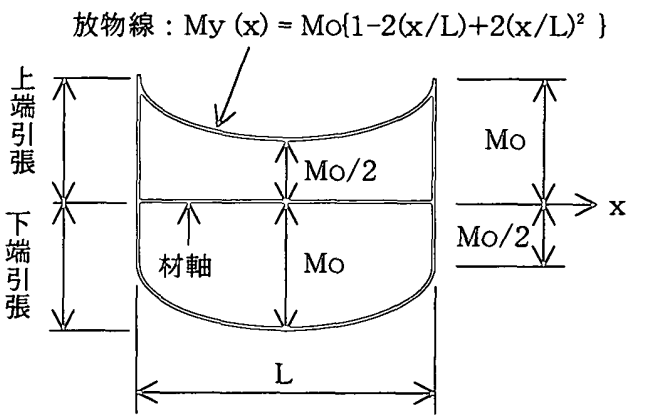

図 14 P S 部分架榜のはりの降伏曲げモーメント分布

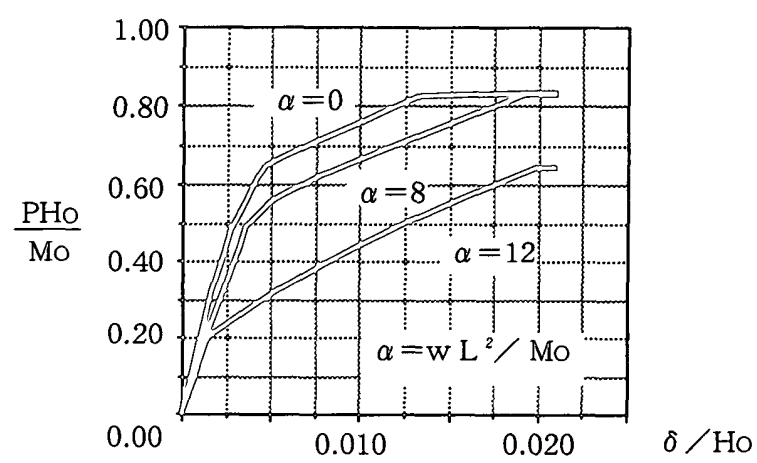

図 15 P S 部分架權の荷重一変形関係 


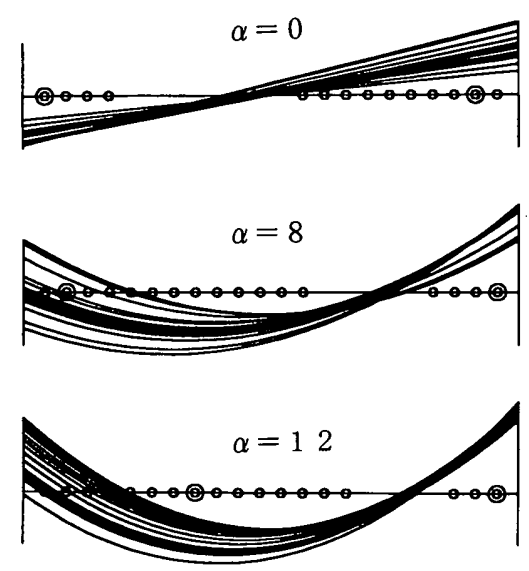

○ひび割れ状態 ○降伏状態

図 16 P S 部分架構のはりの曲げモーメント分布

素 の計 5 要素であり, 又, はりのセグメント分割数 : nzは, 文献 20）等を参考に, 塑性ヒンジ長さを次式により算定することとし, それに見合う24とした。

$$
\ell_{\text {eq }}=\left(0.5+0.03 \frac{\mathrm{a}}{\mathrm{D}}\right) \mathrm{D}
$$

ここに，aは，せん断スパン，Dは，はりせいである。

解析パラメー夕は，一定鈶直等分布荷重 $: \mathrm{w}=\alpha\left(\mathrm{Mo} / \mathrm{L}^{2}\right)$ であ り，積載荷重の相違が応答挙動に及ほす影響を調べるため， $\alpha=$ $0.0,8.0,12.0$ のつのケースについて解析を行った。尚, 極限解析 により求めた各ケースの崩塄荷重は, それぞれ，0.81903( $\mathrm{Mo} / \mathrm{Ho}) ， 0.81932(\mathrm{Mo} / \mathrm{Ho})$ 及び0.61791 (Mo/Ho) である。

代表的結果を，図15～図17示す。図15は，荷重：P 柱頭部の 横方向変位との間の関保を示したものであり，又，図16及び図17 には，それぞれ，新たなひび割れあるいは降伏が生じた各変形レべ ルにおけるはりの曲げモーメント分布と部分架構の変形性状を示 す。さらに，図16には，最終状態におけるひび割れ及び降伏領域の 進展状況も，併せて示している。

この部分架構は，積載荷重の値の相違により，かなり異なった変 形性状を示すが，本解析解は，いずれのケースについても，崩壊荷 重, 崩塄モード共に，極限解析と良好に一致する。又，文献21）等 で指摘されている，鉆直荷重により生じるはりのたわみ性状も十分 再現されており,この種の変断面強度部材についても, 非常に少な い要素数, 自由度数で, その弾塑性崩壊举動を的確に追跡しうるこ とがわかる。

\section{5.まとめ}

本報告では，近藤が文献17）等で提案した骨組棈造離散化解析手 法を R C 骨組に適用し，ハイブリッド型応力法による R C 部材要素 モテルの誘導を行った。又,いくつかの数值解析により，誘導した 要素モデルの精度, 有効性の检証を行った。本報告で提示した R C 部材要素モデルの特長は, 以下のように要約される。

1）従来のモテルでは非常に困難であった，任意の部材中間分布荷 重の影響を，精度よく，又，統一的に評価することが可能であ
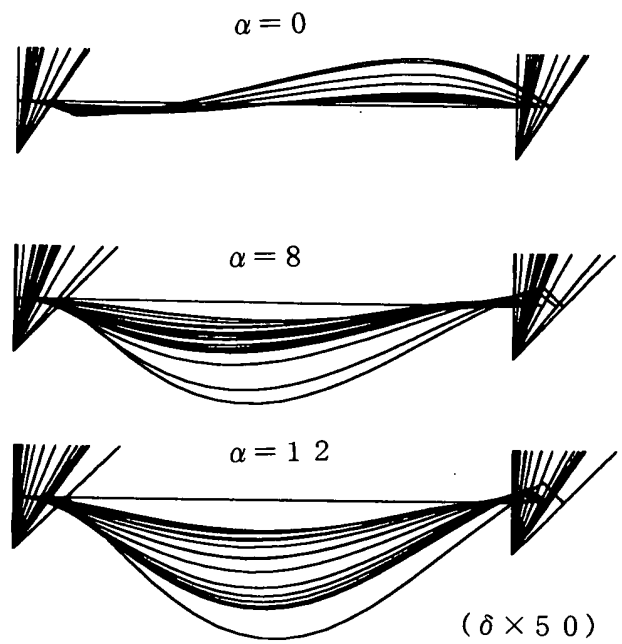

図 17 P S 部分架構の変形性状

る。

2 ) 部材要素内部における独立な状態量を, 平衡方程式からその分 布形状が一義的に定まる合応力としているので, 部材軸に沿っ たはり柱断面の剛性分布がどのような状態となっても, 何等 の矛盾, 問題も生じない。

3）一方, 損傷の進行と共にその分布性状が時々刻々変化していく 変位については, 合応力と断面柔性の積として与えられる一般 化ひずみを，材軸方向について積分することにより求めるとい う手法を用いているため, その変化を的確に追跡することがで きる。

4) 各部材要素を, 材軸方向に微小なセグメントに分割し, はり柱 の断面剛性を, 各セグメントごとに評価するという剛性評価法 を用いているので, 部材要素内の任意の位置にある剛域や塑性 ヒンジを含む変断面部材の剛性や応答に及ぼすその影響を的確 に評価することができる。

5 ）断面特性の定式化の方法として, $\mathrm{M}-\mathrm{N}$ 応力空間内に載荷曲線 を想定するという方法を用いているので, ひび割れ曲線：f及 び降伏曲線： g を適切に設定することにより, 軸力と曲げモー メントとの間の相互作用を考慮した断面特性を設定することが できる。

6)はり柱理論を基礎とした標準的有限要素離散化手法が用いられ ているので, 立体部材要素への拡張, 一般化が, 比較的容易で ある。

尚, 本報告で提示したハイブリッド型応力法 $\mathrm{R} C$ 部材要素モデル は，前述のように，はり柱断面の平面保持を仮定したTimoshenko はり柱理論を基礎に展開されたものであり, 従って, 平面保持の仮 定の適用が困難な，例えば，鉄筋とコンクリートの間の付着すべり や，それに伴なう断面のゆがみ，さらには，部材軸線とは直交しな い斜めひび割れの評価等については，今後の課題であるき4)。

\section{謝 辞}

本研究は, 日本計算工学会研究分科会（研究項目 3 : ハイブリッ ド型応力法 1 次元要素による固体力学諸問題解析プログラムの開発 主查：近藤一夫）で行われたものであり，河内 武（清水建設 


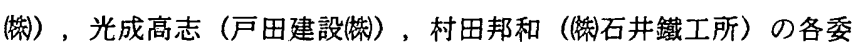
員には有益なるご助言をいただいた。ここに記して，謝意を表しま す。

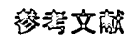

1）稻田祐二，川端康洋，角徽三：ハイブリッド型応力法による鉄筋コン クリート骨組の解析（その1：平面梁・柱部材要素の解析モデル の誘毞），日本建筑学会中国・九州支部合同研究報告（棈造 系) , pp.241 244, 1993.3

2）稲田祐二, 川端康洋, 解徽三: ハイブリッド型応力法による铁筋コン クリート骨組の解析（その 2 : 山型ラーメンの解析例），日本建筑学

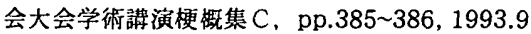

3）稲田祐二, 川端康洋, 近藤一夫, 角徹三: ハイブリッド型応力法によ る跌筋コンクリート骨組の解析（その $3:$ 新断变形の影漹につい $\tau ）$ ，日本建築学会中国支部研究報告, pp.41 44, 1994.3

4）稲田祐二, 川端康洋。近藤一夫，角徽三：ハイブリッド型応力法によ る鉄筋コンクリート骨組の解析（その 4：要素内変位埸の算定 法），日本建筑学会中国支部研究報告，pp.169 172, 1995.3

5) Giberson, M.F. : Two Nonlinear Beams with Definitions of Ductility, Proc. ASCE, Vol.95, No.ST2, pp.137 157, 1969.2

6) Aoyama, H. and Sugano, T. : A Generalized Inelastic Analysis of Reinforced Concrete Structures Based on the Tests of Members, Recent Researches of Structural Mechanics-Contributions in Honor of the 60th Birthday of Prof. Y. Tsuboi, Uno Shoten, Tokyo, pp.15 30, 1968.

7 ) Takizawa, H. : Notes on Some Basic Problems in Inelastic Analysis of Planar R/C Structures（Part1），日本建築学会論 文報告集, No.240, pp.51 62, 1976.2

8）表佑太郎，武田寿一：铁筋コンクリート造煙突の弹塑性応答に関する 研究（その 1)，日本建策学会論文報告集，No.215, pp.21 29, 1974.1

9 ) 荒川利治, 田村正, 洪忠意 : 桑域モテルによる柱及び壁柱平面架構の 㓦力と変形（その1），日本建築学会構造系論文報告集, No.420, pp.19 30, 1991.2

$10)$ Kaba, S. A. and Mahin, S. A. : Refined Modelling of Reinforced Concrete Columns for Seismic Analysis, EERC Report, No.84/03, University of California, 1984.4

1 1) Takizawa, H. and Aoyama, H. : Biaxial Effects in Modelling Earthquake Response of $\mathrm{R} / \mathrm{C}$ Structure, Int. J. Earthq. Eng. Struct. Dyn., Vol.4, No.5, pp.523 552, 1976

12 ）福澤栄治, 破绮浩, 高橋元美：柱の変動軸力を考虑した R C 造骨組の 弹塑性解析（その1），日本建築学会構造系論文報告集，No.372, pp.31 43, 1987.2

13）芳村学, 青山博之. 川村満：2 方向外乱を受ける铁筋コンクリート棈 造物の解析（その1），日本建築学会論文報告焦，No.298， pp.31 41, 1980.12

14 ）孪康悬，小谷俊介，肖山博之: 軸力ー曲什モーメントの相互作用を考 處した R C 造立体骨組の弹塑性地霞応答, コンクリート工学年次論文 報告集，pp.125 130，1990。
15）市之瀬敏勝，滝口克己：鉄筋コンクリート柱の部材モテルに関する比 較研究，日本建築学会構造系論文報告集，No.401，pp.64７6， 1989.7

16 ）小谷俊介：RC造建築物の地震応答解析の現状と問題点, コンクリー 卜工学, Vol.31, No.8, pp.15 23, 1993.8

17 ）近藤一夫 : 除構造骨組の塑性崩罗解析，培風館， 1991.7

18 ）例えば，色部誠，河角誠，安達洋監訳：コンクリート構造物の塑性解 析, 丸善, pp.10 12, 361 364, 1985.7 (Chen, W. F. : Plasticity in Reinforced Concrete, McGraw-Hill, 1982)

19）日本建筑学会：建筑耐震設計における保有酎力と变形性能，pp. 331 333 , pp. $537 \sim 543,1990.10$

$20 ）$ 日本建築学会：プレストレストコンクリート設計施工規準・同解説, pp.317 398, 1987

21 ) Mohit, S. M. P. and Shimazu, T. : The Behaviour of Beams in Reinforced Concrete Frames under the Combines Action of Vertical and Horizontal Loadings, 日本建策学会構造 系論文報告集，No.372，pp.72～85，1987.2

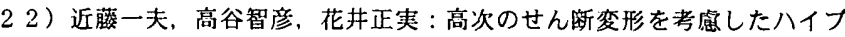
リッド型応力法はり柱要素モテルに関する研究（その1）平面はり柱 要秉の一般的定式化，日本建策学会構造系論文集，No. 488,pp.57 $66,1996.10$

注 1） 4. 2 項及び 4. 3 項に示した数値解析例では，提示したR Cはり柱 要素モテルの精度の検証を主な目的としているため，载荷曲線g，fの 形状を, 崩垻荷重, 崩罗機構等の理論解が比皎的容易に求められる (23. a,b) 式としているが，g，fをMとNの関数とした場合の解析結果 については，例えば，文献 2) 等に示されている。

注 2 ）ここで行った数值解析では，甽域部分のヤング保数及び断面 2 次モ一 メントを，図6に示すように，可撓域部分の $10^{6}$ 倍としている。尚， 必要ならば，甽性無限大の領域を設定することも容易に可能であり， そうした場合にも，該当区間内でコンプリメンタリーエネルギーが0 となるのみであり，何等の矛盾，不都合も生じない。

注 $3 ） 3.2$ 項で述べたように，本研究では，計算の简略化を計るため，弾性 コンプリメンタリーエネルギーの算定を除いて，一般化ひずみ，合応 力は，各セグメント内で一定としており，一般化ひずみを材軸方向に 䅪分することにより変位を求める際にも，同様な処理を行っている。 4. 1節に示した例題における誤差は，こうした計算処理に起因するも のである。

注 4）断面のゆがみやそれに伴なって生じる高次のせん断変形を考䖈したは り柱理論を基磼としたハイブリッド型応力法はり柱要素モデルについ ては，例えば，文献22）等に展開されている。

（1997年 9 月 1 日原稿受理，1998年 1 月13日採用決定） 